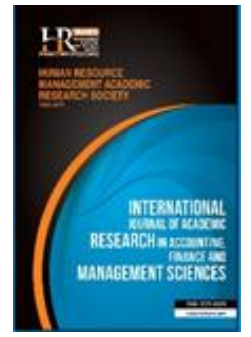

International Journal of Academic Research in Accounting, Finance and Management Sciences

Vol. 10, No.2, April 2020, pp. 171-183

E-ISSN: 2225-8329, P-ISSN: 2308-0337

(c) 2020 HRMARS

www.hrmars.com

To cite this article: Aruna; F. E., Oshiole, S., Amahalu, N. N. (2020). Effect of Taxes on Net Investment of Listed Communication Firms in Nigeria., International Journal of Academic Research in Accounting, Finance and Management Sciences 10 (2):171-183

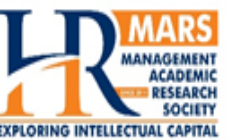

\title{
Effect of Taxes on Net Investment of Listed Communication Firms in Nigeria
}

\author{
Fatai Elamah Aruna ${ }^{1}$, Samuel Oshiole ${ }^{2}$, Nestor Ndubuisi Amahalu ${ }^{3}$ \\ ${ }^{1}$ Hartland Nigeria Limited, Auchi, Edo State, Nigeria, ${ }^{2}$ E-mail: elamselams@gmail.com \\ ${ }^{2}$ Department of Accountancy, Auchi Polytechnic Auchi, Edo State, Nigeria, ${ }^{1}$ E-mail: bigsam031@yahoo.com \\ ${ }^{3}$ Department of Accountancy, Nnamdi Azikiwe University Awka, Anambra State, Nigeria, \\ ${ }^{3}$ E-mail:nn.amahalu@unizik.edu.ng
}

\begin{abstract}
This study determined the effect of Taxes on Net Investment of Listed Communication Firms in Nigeria for a period of ten years spanning from 2010 and 2019. Eight Communications firms were purposively sampled from a population of eleven listed Communication firms in Nigeria. The proxies for Taxes include Information Communication Tax, Education Tax and Company Income Tax, while Net Investment served as the dependent variable. Pearson Correlation Coefficient and Panel Least Square (PLS) Regression analysis via E-Views 10.0 statistical software were used to test the hypotheses of the study. The result of this study showed that Information Communication Tax, Education Tax and Company Income Tax have a significant negative effect on Net Investment at 5\% level of significance respectively. This study therefore recommends inter alia that Federal Government of Nigeria should reduce the amount of tax liability at the end of the year thus making funds available for further investment.

Key words

Taxation, Net Investment, Information Communication Tax, Education Tax

Received: 19 May 2020 (C) The Authors 2020

Revised: 30 Jun 2020 Published by Human Resource Management Academic Research Society (www.hrmars.com)

Accepted: $\quad 09 \mathrm{Jul} 2020 \quad$ This article is published under the Creative Commons Attribution (CC BY 4.0) license. Anyone may Published Online: $28 \mathrm{Jul} 2020 \quad \begin{aligned} & \text { reproduce, distribute, translate and create derivative works of this article (for both commercial and } \\ & \text { non-commercial purposes), subject to full attribution to the original publication and authors. The full }\end{aligned}$ terms of this license may be seen at: http://creativecommons.org/licences/by/4.0/legalcode
\end{abstract}

\section{Introduction}

Over the past decades, the relationship between corporate investment and taxation has become increasingly central to economic and tax policy and therefore also a focus of empirical research. Against the backdrop of economic globalisation and the associated increase in capital mobility, corporate taxation have become one way for governments to compete with one another to attract investment and thereby create jobs. As a result of this competition, most industrialised countries have cut corporate tax rates, in some cases by a large margin. These reductions are generally financed by broadening of the tax base, with limitations in depreciation allowances and offsetting of tax losses (Amahalu et al., 2019). The development of telecommunications in Nigeria began in 1886 when a cable connection was established between Lagos and the colonial office in London. By 1893, government offices in Lagos were provided with telephone service, which was later extended to llorin and Jebba in the hinterland. A slow but steady process of development in the years that followed led to the gradual formation of the nucleus of a national telecommunications network. In 1923, the first commercial trunk telephone service between Itu and Calabar was established. Between 1946 and 1952, a three-channel line carrier system was commissioned between Lagos and Ibadan and was later extended to Oshogbo, Kaduna, Kano, Benin, and Enugu; thus 
connecting the colonial office in London with Lagos and the commercial centers in the country with local authority offices. The main transmission medium during the pre-independence era was unshielded twisted pair. This evolved later from rural carrier systems on high gauge lines to line carrier systems of twelvechannel capacity. Small- to medium-capacity systems employing VHF and UHF radio were introduced around 1955. By about 1960, a manual telex exchange of sixty subscriber lines was in service in Lagos. While all the above efforts were essentially aimed at improving internal telephone services in Nigeria, external telephone services in the pre-independence period were wholly owned by Cable and Wireless of the United Kingdom, which was a colonial private company. Cell phones have become a lot smaller over the years, but they're bigger than ever in functionality and popularity (Akele, 2018). However, investment decisions of companies are mostly fiscal weapon. Taxation (such as information communication tax, education tax, company income tax, personal income tax, petroleum profit tax, custom duties, export duties, excise duties, value added tax etc) is regarded as an indispensable measure towards any nation's development among the various sources of achieving economic goal of any nation precisely developing country like Nigeria. The question then is what is the concern of tax in investment decision of companies? It is well understood that taxation can distort investment plans by reducing the after-tax returns to new investment.

Nigeria is a nation with federal political structure that adheres strictly to the same principles of fiscal regime and this system has serious implications on how the tax system is managed. It is characterized by unnecessary complex, distortion and largely inequitable taxation laws that have limited application in the formal sector that dominates the economy. Tax is an essential source of government revenue that defrays the expenditures incurred by government by making it mandatory on tax payers (Okeke et al., 2018). Tax is a valuable instrument of public finance whose magnitude affects the level of economic activity of an economy and is utilized not only for raising revenue of government to finance its programmes but also regulates the direction of economic performance of the economy. A system of tax vary from one country to the other and because it is a socio/political and economic model representing society's social, political and economic needs and aspiration at any given time, the Nigerian tax system is dynamic and is continually changing to meet the needs of the constituents of the society (Aminu \& Eluwa, 2018). Tax is a system of raising money from individual person or corporate body for the purposes of government developmental programmes. It is rather a compulsory contribution imposed by the government on tax payers in return to identifiable benefit of living in a relatively educated, healthy and safe society. Though tax are imposed to regulate the production of certain goods and services, protection of infant or certain key industries as well as means of curbing inflation and meeting up the operational costs of governance. Taxes in Nigeria are imposed to regulate certain economic activities such as to influence economic activities in the country, bridge the inequality gap between the rich and the poor, to curtail consumption of undesirable goods and services, to correct a country's balance of payment and tax is used to attract investors. Consequently there are no companies that do not make investment decision at one time or the other which requires taxation (such as information communication tax, education tax company income tax etc) to be properly and effectively planned to achieve the companies' goals and objectives. It is based on these facts that this research sought to ascertain the effect of taxes on net investment of listed communication firms in Nigeria.

\subsection{Statement of the Problem}

The interaction between investment and financing decisions is arguably the central issue in corporate world. It is now well established that a firm's financing choices may affect its investment decisions because taxes, issuance costs, agency conflicts, and information problems associated with debt and equity will affect the firm's cost of capital, drive a wedge between the cost of internal and external funds, and alter managers' incentives to take different types of projects. An issue that has received particular attention is the sensitivity of investment to internally generated cash flow. Theoretically, a firm might invest more when cash flow is high for three reasons: (i) internal funds may be less costly than external funds, (ii) managers may overspend internally available funds, and (iii) cash flow may simply be correlated with investment opportunities. Taxes (such as information communication tax, education tax and company income tax) can affect investment decisions of a company because it is the amount taken from the profit of the company. This could be invested back to business to generate more profits to the company thus 
increasing the shareholders' value. Company business activities are surrounded by risks and uncertainties and such risk could lead to losses of money invested, losses of material in site and the causes of all these things could be having not made good decisions on how to invest.

The linkage between tax and net investment has received persistent attention in both the academic literature and policy debates. One of the main drivers of economic growth is investment and how taxes affect investment behavior of firms is, indeed, a question of great importance. It is well understood that company taxation can have large effects on firms' investment decisions. Taxes (such as information communication tax, education tax and company income tax) impinge directly on the incentive to accumulate capital and to perform research. To tackle this issue, starting from the mid-80s many organization for economic cooperation and development (OECD) countries have undertaken significant reforms of their business tax system under the general objective of reducing the distortionary effects of taxes on investment, in way to foster firms' competitiveness and attract foreign investments (Okeke et al., 2018). There are contrasting views on whether taxes affect corporate investment. Traditional models of dividend taxation assume that the cost of capital of firms, and thus corporate investment, depends on the level of taxation (Chen \& Chen, 2012; Fama \& French, 2015). In contrast, the new view of dividend taxation assumes that investments are funded by retained earnings rather than new equity (Estevão \& Samake, 2017; Rauh, 2017).

The relationship between tax and net investment has produced mixed, inconsistent results, providing no conclusive evidence whether the relationship is positive (Fazzari et al., 2016; Oliveira \& Fortunato, 2016), negative (Bond et al., 2014; Chirinko, 2015), or neutral (Jorgenson, 2013), thereby constituting variable gap and sectoral gap. In order to fill the observed gaps in literature, this study considered tax (proxied by information communication tax, education tax and company income tax) as against prior studies that considered only company tax) in order to close the variable gap, while the sectoral gap was resolved by concentrating on Communication Sector as majority of the study on this theme focused on deposit money banks (to the best knowledge of the researcher). Hence, the need to ascertain the effect of tax on net investment of listed communication firms in Nigeria from 2010-2019.

\subsection{Objectives of the Study}

The main objective for this study is to determine the effect of Taxes on Net Investment of listed Communication firms in Nigeria.

The specific objectives are to:

i. Ascertain the effect of Information Communication Tax on Net Investment of Communication firms listed on Nigeria Stock Exchange.

ii. Determine the effect of Education Tax on Net Investment of Communication firms listed on Nigeria Stock Exchange.

iii. Assess the effect of Company Income Tax on Net Investment of Communication firms listed on Nigeria Stock Exchange.

\subsection{Research Hypotheses}

To answer the research questions, three null hypotheses were formulated:

Ho $_{1}$ : Information Communication Tax has no significant effect on Net Investment of Communication firms listed on Nigeria Stock Exchange.

Ho $_{2}$ : Education Tax has no significant effect on Net Investment of Communication firms listed on Nigeria Stock Exchange.

$\mathrm{Ho}_{3}$ : Company Income Tax has no significant effect on Net Investment of Communication firms listed on Nigeria Stock Exchange. 


\section{Literature review}

\subsection{Conceptual review}

\subsubsection{Tax}

Tax is a compulsory charge imposed by a public authority on the income and properties of individuals and companies as stipulated by the government Decree, Acts or Laws irrespective of the exact amount of service of the payer in return (Abiahu \& Amahalu, 2017). Tax payment is not for the direct exchange of good and/or services but a transfer of resources and income from the private sector to the public sector in order to achieve some of the nation's economic and social goals. Such goals may be in for of high level of employment, stable prices, rapid growth of gross national product, favourable balance of payments position, promotion of a free market economy, satisfaction of collective demands, equitable income redistribution, promotion of infant industries, the encouragement of priority sector, encouragement of balance population development and promotion of labour and capital development.

\subsubsection{Information Communication Tax}

Information technology tax is tax imposed on companies engaging in information communication technology. However not all companies in Nigeria are subject to information technology tax. Section 12(2) of the NITDA Act provides that certain companies are under obligation to pay information technology tax and such companies include: Telecommunications companies, finance institution, insurance companies, pension managers, internet service providers and cyber companies. These companies are expected to pay the tax at the taxable rate of $1 \%$ of their gross profit. Unlike companies income tax where the tax is charged based on the net income or profit (that is income after deduction of expense or exempted income or deductible income from the gross or aggregate income), information technology tax is taxable on the gross profit of a company before any deduction is made. Some has argued that this tax is an additional burden on companies considering the $30 \%$ of companies' income tax already liable for such could lead to multiple tax from the same tax base or income. Some also argued that it could lead to tax evasion and create unnecessary complexity in the administration of tax. It is important to note that it is not all companies listed above have the liability to pay. To be liable under the Act, such companies must earn at least an annual profit of 1 million Naira. This caveat tend to protect such companies which originally would have fallen under the Act but make little profit on an annual basis. This caveat can also be used as an escape route by companies to escape tax liability by hidden some profit made by it. The information technology tax is administered by the Federal Inland Revenue Services (FIRS). Once the tax is collected, it is put into a trust fund account called the Information technology Development Agency trust fund. This money is exempted from income tax (Atuma, 2018).

\subsubsection{Education Tax}

The Education Tax Act was promulgated as Education Tax Decree no 7 of 1993. It was amended through the decree no 40 of 1998 to mainly provide for appointment of committee members by the Board of Trustees. It imposed a tax at the rate of $2 \%$ on Profit before Tax earned by all companies registered in Nigeria including those operating in the petroleum sector of the economy. That is, the income chargeable to this tax is the assessable profit of any company registered in Nigeria. An education tax of $2 \%$ of assessable profits is imposed on all companies incorporated in Nigeria. This tax is viewed as a social obligation placed on all companies in ensuring that they contribute their own quota in developing educational facilities in the country.

\subsubsection{Company Income Tax}

Company Tax is established by the Companies Income Tax Act (CITA) CAP C21 2004 LFN for both resident and non-resident companies in Nigeria. A resident company is one whose operations are carried and managed and is liable to Nigerian tax law. On the other hand, a non-resident company is one whose portion of its income is obtainable in Nigeria and is liable to any such laws in force in any given country outside Nigeria. Company tax is controlled and managed by the Federal Inland Revenue Service (FIRS) through various large tax offices and incorporated tax offices. Companies are taxed on the basis on certain 
expenditure in determining whether they are incurred wholly, exclusively, necessarily or reasonably in earning the income. All companies in Nigeria are liable to pay companies Income Tax on their global profits accruing in, brought into, derived from or received in Nigeria. The CITA however, exempts the profits of any company engaged in ecclesiastical, charitable or educational activities of a public character in so far as such profits are not derived from a trade or business carried on by such company. CITA also exempts the profits from taxation of any company formed for the purpose of promoting sporting activities where such profits are wholly expendable for such purpose. The tax rate applied to small companies is $20 \%$ on the taxable profit instead of the $30 \%$ of a normal trade or business.

\subsubsection{Net Investment}

Net investment is the amount spent by a company or an economy on capital assets, or gross investment, less depreciation. Net investment helps give a sense of how much money a company is spending on capital items used for operations, such as property, plants, equipment and software. Subtracting depreciation from this amount, or capital expenditure (CAPEX) (since capital assets lose value over their life because of wear and tear, obsolescence, etc.), provides a more accurate picture of the investment's actual value. Net cash flow refers to the difference between a company's cash inflows and outflows in a given period. In the strictest sense, net cash flow refers to the change in a company's cash balance as detailed on its cash flow statement (Vaidya, 2018).

\subsubsection{Information Communication Tax and Net Investment}

Information Technology (IT) is the automation of processes, controls, and information production using computers, telecommunications, software and ancillary equipment such as automated teller machine and debit cards. Communication technology deals with the physical devices and software that link various computer hardware components and transfer data from one physical location to another (Lin, 2017). A structured approach in the development of tax policy can generate positive effects on tax certainty along several channels, for instance by engaging key participants of the private sector in the consultation, preand post-reform/change, and by having safeguards to guarantee a good drafting of tax law and ultimately the clarity of tax legislation. Zwick and Mahon (2017) found a negative relationship between tax and cash flow of US firms, while Garrison (2018) found a positive relationship between tax and risky investments.

\subsubsection{Education Tax and Net Investment}

The primary responsibility of every government all over the world is to ensure security, freedom and welfare of its citizen. For instance, Section 16(1b) of the 2011 Constitution of the Federal Republic of Nigeria states that "the government has the responsibility of ensuring the maximum welfare, freedom and happiness of its citizens" (Federal Government of Nigeria, 2011). To effectively carry out its primary function and other subsidiary functions, governments need adequate funding. Unfortunately, Government responsibilities continue to increase over time especially in developing country like Nigeria; as a result of growing population of citizens, and technological development. Agbionu et al. (2017) concluded that an increase in average education expenditure can increase long-run growth particularly in the rich countries. Brunela (2018) compared the impact of investment in health with investment in education and showed that the impact of investment in health has a stronger impact on economic growth than investment in education. Investment in education is a key driver of future development. There is empirical evidence that education expenditure is positively associated with future economic growth (Federici \& Parisi, 2015).

\subsubsection{Company Income Tax and Net Investment}

Statement of Financial Accounting Standards (SFAS) 95's definition of investing activities includes making and collecting loans; acquiring and disposing of debt or equity instruments; and acquiring and disposing of property, plant, equipment, and other productive assets. More specifically, investing cash inflows include receipts from collecting or disposing of loans; receipts from the sale of debt or equity securities of other entities; and receipts from sales of property, plant, equipment, and other productive assets, including business dispositions. Similarly, investing cash outflows include payments to make or acquire loans; payments to acquire debt or equity securities of other entities; and payments to acquire 
property, plant, equipment, and other productive assets, including capitalized interest payments and business acquisitions. Taxation is a tool by government in fashioning various aspects of economic growth.

Lewellen and Lewellen (2016) used a sample of firm-level data for OECD countries to investigate whether firms facing higher corporate tax rates on their profits exhibit lower total factor productivity (TFP) and investment levels compared to firms facing lower corporate tax rates.

\subsection{Theoretical framework}

\subsubsection{Free Cash Flow Theory (FCF)}

Free Cash Flow theory was propounded by Jensen in 1976. Free cash flow (FCF) represents the cash that a company is able to generate after required investment to maintain or expand its asset base. It is a measurement of a company's financial performance and health. Free cash flow (FCF) is the cash flows available to all investors in a company, including common stockholders. FCF provides a useful valuation technique that can derive the value of a firm or the value of a firm's common equity. FCF measures the level of cash available to a company's investors net of all required investments in working capital and fixed capital, or capital expenditures (CAPEX), for a period. FCF or FCFF is an important measure because it allows a company to pursue opportunities that enhance shareholder value (Amahalu \& Ezechukwu, 2017). Excess cash can expand production, develop new products, make acquisitions, pay dividends and reduce debt. As free cash flow increases, balance sheet strength rises. However, it is important to note that negative free cash flow is not a bad indicator in itself. If free cash flow is negative, it could be a sign that a company is making significant investments. If these investments earn a high return, the strategy has the potential to add value in the long run.

\subsection{Empirical review}

Zwick \& Mahon (2017) estimated the effect of temporary tax incentives on equipment investment using shifts in accelerated depreciation. Analyzing data for over 120,000 firms, the study presented three findings. First, bonus depreciation raised investment in eligible capital relative to ineligible capital by 10.4 percent between 2001 and 2004 and 16.9 percent between 2008 and 2010. Second, small firms responded 95 percent more than big firms. Third, firms responded strongly when the policy generates immediate cash flows, but not when cash flows only come in the future. This heterogeneity materially affects investmentweighted estimates and supports models in which financial frictions or fixed costs amplify investment responses.

Amuka \& Ezeudeka (2017) investigated whether the incentive policy has brought any significant change in the pattern of flow of foreign direct investment to the non-oil sector (1999-2016) in Nigeria. The study adopted a multiple regression model which was transformed into log-log model in the analysis. Regime switch model helped us to evaluate the effectiveness of the policy introduced in late 1999. Both company income tax and investment allowance appeared with the right sign. Result suggested that the tax incentive policy introduced changed the flow of foreign investment to the non-oil sector, showing that the country's tax incentives can help revive the ailing non-oil sector.

Amahalu \& Ezechukwu (2017) assessed the extent at which cash holding affects financial performance of quoted insurance firms in Nigeria over the period 2010-2015. Three hypotheses were formulated in line with objective of the study; Ex-post facto research design and time-series data were adopted and the data for the study were obtained from fact books, annual reports and account of the quoted insurance companies under study. Pearson coefficient of correlation and multiple regressions were applied for the test of the three hypotheses formulated with aid of STATA 13 statistical software. Findings showed that cash holding (proxy by cash to total book value of assets and cash) has a positive and statistical significant effect on financial performance (proxy by Return on Asset, Return on Equity and Tobin's Q) at 5\% significant level. Based on these findings, the study recommends among others that insurance companies should adequately mange how they re-invest their resource so as to prevent any form of mismanagement of resource that can guarantee their existence in business.

Brunela (2018) examined the effect of tax on the economic growth in the case of a small and open developing country as Albania. The main objective of this study is to empirically investigate the impact of fiscal policy on the level of economic growth in Albania. The study covered the period between 1994 and 
2016. The co integration technique with its implied Error Correction Model was used for the study. Three indicators of fiscal policy are used: profit tax, government expenditure and external debt. The result indicates that these three indicators have a positive impact on the economic growth in Albania. The study came to the result that the good use of the fiscal policy will improve the growth of economy in Albania.

\section{Methodology of research}

\subsection{Research Design}

The research design employed in this study is the ex-post facto research design.

\subsection{Population of the Study}

The population of this study consists of all the eleven (11) Communication companies trading on the floor of Nigeria Stock Exchange as at $31^{\text {st }}$ December, 2019. They include; Chams Plc, Courtville Business Solutions PIc, CWG Plc, E-Tranzact International Plc, Mass Telecommunication Innovations Plc, MTECH Communications PIc, NCR (Nigeria) Plc, Omatek Ventures Plc, Tripple Gee and Company Plc, Starcomms Plc, IHS PIc.

\subsection{Sample Size and Sampling Technique}

Eight (8) Communications companies were purposively selected as the sample size of this study with the utilization of Purposive sampling method Data were gathered from the published financial statements of the eight (8) Communication companies for a ten (10) year period spanning from 2010-2019. They include: Chams PIc, Courtville Business Solutions PIc, E-Tranzact International Plc, Mass Telecommunication Innovations PIc, MTECH Communications PIc, NCR (Nigeria) Plc, Omatek Ventures Plc, Tripple Gee and Company Plc.

\subsection{Source of Data}

This study made use of secondary data precisely. The data sets were sourced from publications of the Nigerian stock exchange (NSE), fact books and the annual report and accounts of the selected quoted Communication companies.

\subsection{Operationalisation of Variables}

\begin{tabular}{|c|c|}
\hline Variables (code) & Operational Definitions \\
\hline \multicolumn{2}{|c|}{ Dependent Variable (Net Investment) } \\
\hline Net Investment (NETIV) & Capital Expenditures - Depreciation \\
\hline Independent Variable (Taxes ) \\
\hline Proxies: \\
\hline Information Communication Tax (ICT) & $1 \%$ of Gross Profit \\
\hline Education Tax (ET) & $2 \%$ of Profit before Tax \\
\hline Company Income Tax (NETIV) & $30 \%$ of the taxable profit \\
\hline Control Variable & Natural logarithm of total asset \\
\hline Firm Size (FSZ) & Total debt/Total equity \\
\hline Leverage (LEV) &
\end{tabular}

\subsection{Model Specification}

The following research models were formulated in line with the research hypotheses in order to empirically determine the effect tax on net investment:

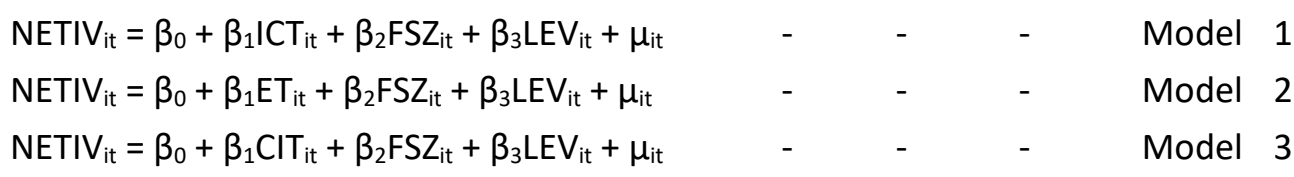

Where: 
NETIV $_{i t}=$ Net Investment of firm $i$ in period $t ; \mathrm{ICT}_{\text {it }}=$ Information Communication Tax of firm $i$ in period $t ; \mathrm{ET}_{\text {it }}=$ Education Tax of firm $i$ in period $t ; \mathrm{CIT}_{\text {it }}=$ Company Income Tax of firm $i$ in period $t ; \mathrm{FSZ}_{\text {it }}=$ Firm Size of firm $i$ in period $t$; LEV $V_{i t}=$ Leverage of firm $i$ in period $t ; \mu_{i, t}=$ component of unobserved error term of firm $i$ in period $t ; \beta_{0}=$ constant term; $\beta_{1} \beta_{2}$ and $\beta_{3}=$ are slope to be estimated of firm $i$ in period $t ; i=$ firm identifier (8 firms); $t=$ time variable $(2010,2011, \ldots$ 2019) - (Ten Years).

\subsection{Data Presentation and Analysis}

Table 1. Pearson Correlation Matrix

\begin{tabular}{|l|c|c|c|c|c|c|}
\hline & NETIV & ICT & ET & CIT & FSZ & LEV \\
\hline NETIV & 1.000 & 0.608 & 0.027 & -0.683 & 0.623 & 0.205 \\
\hline ICT & 0.608 & 1.000 & 0.653 & -0.021 & 0.312 & -0.091 \\
\hline ET & 0.027 & 0.653 & 1.000 & 0.606 & -0.185 & -0.230 \\
\hline CIT & -0.683 & -0.021 & 0.606 & 1.000 & -0.658 & -0.406 \\
\hline FSZ & 0.623 & 0.312 & -0.185 & -0.658 & 1.000 & 0.275 \\
\hline LEV & 0.205 & -0.091 & -0.230 & -0.406 & 0.275 & 1.000 \\
\hline
\end{tabular}

Source: E-Views 9.0 correlation output, 2020

\subsection{Interpretation of Pearson Correlation Matrix}

From the findings on the correlation analysis in table 1 , the study found that there was positive correlation coefficient between ICT, ET, FSZ, LEV and NETIV by correlation factors of $0.608,0.027,0.623$ and 0.205 respectively. However, CIT and NETIV were found to have negative correlation with correlation coefficients of -0.683 .

\subsection{Test of Hypotheses}

\section{Test of Hypothesis I}

$\mathrm{Ho}_{1}$ : Information Communication Tax has no significant effect on Net Investment of Communication firms listed on Nigeria Stock Exchange.

$\mathbf{H}_{1}$ : Information Communication Tax has significant effect on Net Investment of Communication firms listed on Nigeria Stock Exchange.

Table 2. Panel Least Square Regression Analysis between ICT and Net Investment of listed Communication firms in Nigeria

Dependent Variable: NETIV

Method: Panel Least Squares

Date: 06/19/20 Time: 05:25

Sample: 20102019

Periods included: 10

Cross-sections included: 8

Total panel (balanced) observations: 80

\begin{tabular}{|c|c|c|c|c|}
\hline Variable & Coefficient & Std. Error & t-Statistic & Prob. \\
\hline C & -2.869281 & 0.969574 & -2.959322 & 0.0041 \\
\hline ICT & -6.692258 & 1.015147 & -6.592403 & 0.0000 \\
\hline FSZ & 1.075491 & 0.085017 & 12.65028 & 0.0000 \\
\hline LEV & 0.020114 & 0.020163 & 0.997565 & 0.3217 \\
\hline R-squared & 0.705790 & \multicolumn{2}{|c|}{ Mean dependent var } & 9.766678 \\
\hline Adjusted R-squared & 0.694176 & \multicolumn{2}{|c|}{ S.D. dependent var } & 0.785071 \\
\hline S.E. of regression & 0.434155 & \multicolumn{2}{|c|}{ Akaike info criterion } & 1.217874 \\
\hline Sum squared resid & 14.32525 & \multicolumn{2}{|c|}{ Schwarz criterion } & 1.336976 \\
\hline Log likelihood & -44.71498 & \multicolumn{2}{|c|}{ Hannan-Quinn criter. } & 1.265626 \\
\hline F-statistic & 60.77289 & \multicolumn{2}{|c|}{ Durbin-Watson stat } & 1.905721 \\
\hline Prob(F-statistic) & 0.000000 & & & \\
\hline
\end{tabular}

Source: E-Views 10.0 Regression Output 2020 


\subsection{Interpretation of Regression Result}

In table 2, a panel least square regression analysis was conducted to test the effect of information communication tax on net investment. Adjusted $\mathrm{R}$ squared is coefficient of determination which tells us the variation in the dependent variable due to changes in the independent variable. From the findings in the table 2 , the value of adjusted $\mathrm{R}$ squared was 0.694 , an indication that there was variation of $69.4 \%$ on net investment due to changes in ICT, FSZ and LEV. This implies that only $69.4 \%$ changes in net investment of communication firms could be accounted for by ICT, FSZ and LEV, while $30.6 \%$ was explained by unknown variables that were not included in the model. The probability of the slope coefficients indicate that; $\mathrm{P}\left(\mathrm{x}_{1}=\right.$ $0.0000<0.05 ; x_{2}=0.0000<0.05 ; x_{3}=0.3217>0.05$ ). The co-efficient value of; $\beta_{1}=-6.692258$ for ICT implies that NETIV is negatively related to ICT, though statistically significant at $5 \%$.

The linear regression model becomes;

NETIV $=-2.869281-6.692258 \mathrm{ICT}+\mu$

The implication is that, for there to be a unit/one naira increase in NETIV there will be 6.692258 multiplying effect decrease of ICT. The Durbin-Watson Statistic of 1.905721 suggests that the model does not contain serial correlation. The F-statistic of the NETIV regression is equal to 60.77289 and the associated F-statistic probability is equal to 0.000000 , so the null hypothesis was rejected and the alternative hypothesis was accepted.

Decision

Since the Prob(F-statistic) of 0.000000 is less than the critical value of $5 \%(0.05)$, then, it would be upheld that information communication tax has significant negative effect on net investment of communication firms listed on Nigeria Stock Exchange at $5 \%$ level of significance, thus, $\mathrm{H}_{1}$ is preferred over Ho.

Test of Hypothesis II

Ho. $_{2}$ Education Tax has no significant effect on Net Investment of Communication firms listed on Nigeria Stock Exchange.

$\mathbf{H}_{2}$ : Education Tax has significant effect on Net Investment of Communication firms listed on Nigeria Stock Exchange.

Table 3. Panel Least Square Regression Analysis between ET and Net Investment of listed Communication firms in Nigeria

Dependent Variable: NETIV

Method: Panel Least Squares

Date: 06/19/20 Time: 05:41

Sample: 20102019

Periods included: 10

Cross-sections included: 8

Total panel (balanced) observations: 80

\begin{tabular}{lllll}
\hline \hline \multicolumn{1}{c}{ Variable } & Coefficient & Std. Error & t-Statistic & Prob. \\
\hline \hline C & -1.278598 & 1.124739 & -1.136795 & 0.2592 \\
ET & -1.261297 & 0.508423 & -2.480804 & 0.0153 \\
FSZ & 0.949472 & 0.099238 & 9.567606 & 0.0000 \\
LEV & 0.021777 & 0.024897 & 0.874671 & 0.3845 \\
\hline \hline R-squared & 0.572192 & Mean dependent var & 9.766678 \\
Adjusted R-squared & 0.555305 & S.D. dependent var & 0.785071 \\
S.E. of regression & 0.523528 & Akaike info criterion & 1.592254 \\
Sum squared resid & 20.83019 & Schwarz criterion & 1.711355 \\
Log likelihood & -59.69016 & Hannan-Quinn criter. & 1.640005 \\
F-statistic & 33.88329 & Durbin-Watson stat & 1.651948 \\
Prob(F-statistic) & 0.000000 & & \\
\hline \hline
\end{tabular}

Source: E-Views 10.0 Regression Output 2020 


\subsection{Interpretation of Regression Analysis}

This study adopts panel data which has the advantage of combining both time-series and cross sectional dimensions of the eight listed communication companies for this research. The value of Adjusted $\mathrm{R}$-squared showed that $55.5 \%$ of the total variation in dependent variable is explained by independent variable to the determination of net investment while the remaining $44.5 \%$ is caused by other explanatory factors outside this model and this is captured by the error term. The coefficient result shows that ET ( $\beta_{1}=-$ $1.261297)$ is negatively related with NETIV, while FSZ $\left(\beta_{2}=0.949472\right)$ and LEV $\left(\beta_{3}=0.021777\right)$ are positively related with NETIV. The probability value of the slope coefficients indicate that $\mathrm{P}\left(\mathrm{x}_{1}=0.0153<0.05\right.$; $\left.\mathrm{x}_{2}=0.0000<0.05 ; \mathrm{x}_{3}=0.3845>0.05\right)$. This implies that NETIV has a significant negative relationship with ET; a significant positive relationship with FSZ and non-significant positive relationship with LEV.

The Durbin-Watson figure of 1.651948 indicates the absence of autocorrelation in the regression model. The overall performance of the model is satisfactory as shown by Prob(F-statistics) $=0.000000$.

From the above factual information it is clearly obvious that there is a significant negative relationship between ET and NETIV.

The regression equation is:

NETIV $=-1.278598-1.261297 \mathrm{ET}+\mu$

The implication is that, for there to be a unit/one naira increase in NETIV there will be 1.261297 multiplying effect decrease of ET

Decision

Since the result of the Prob(F-statistic) of 0.000000 is less than the critical value of $5 \%$ significance level, leading to the conclusion that education tax has a significant negative effect on net investment of listed communication firms at $5 \%$ significant level, hence, $\mathrm{H}_{1}$ is accepted.

\section{Test of Hypothesis III}

$\mathrm{Ho}_{3}$ : Company Income Tax has no significant effect on Net Investment of Communication firms listed on Nigeria Stock Exchange.

$\mathbf{H}_{3}$ : Company Income Tax has significant effect on Net Investment of Communication firms listed on Nigeria Stock Exchange.

Table 4. Panel Least Square Regression Analysis between CIT and Net Investment of listed Communication firms in Nigeria

Dependent Variable: NETIV

Method: Panel Least Squares

Date: 06/19/20 Time: 05:50

Sample: 20102019

Periods included: 10

Cross-sections included: 8

Total panel (balanced) observations: 80

\begin{tabular}{lllll}
\hline \hline \multicolumn{1}{c}{ Variable } & Coefficient & Std. Error & t-Statistic & Prob. \\
\hline \hline C & -1.464493 & 1.181232 & -1.239800 & 0.2189 \\
CIT & -1.062804 & 0.532894 & -5.994402 & 0.0000 \\
FSZ & 0.960791 & 0.102538 & 9.370143 & 0.0000 \\
LEV & 0.017764 & 0.025086 & 0.708125 & 0.4810 \\
\hline \hline R-squared & 0.560549 & Mean dependent var & 9.766678 \\
Adjusted R-squared & 0.543202 & S.D. dependent var & 0.785071 \\
S.E. of regression & 0.530605 & Akaike info criterion & 1.619107 \\
Sum squared resid & 21.39713 & Schwarz criterion & 1.738208 \\
Log likelihood & -60.76429 & Hannan-Quinn criter. & 1.666858 \\
F-statistic & 32.31429 & Durbin-Watson stat & 1.635451 \\
Prob(F-statistic) & 0.000000 & & \\
\hline \hline
\end{tabular}

Source: E-Views 10.0 Regression output, 2020 


\subsection{Interpretation of Regression Result}

NETIV $=-1.464493-1.062804 \mathrm{CIT}+\mu$

The above model tested the effect of company income tax on net investment. The result showed that company income tax has a significant negative effect on net investment. This can be seen from the coefficients and probability of t-stat in table $4 ; \beta_{1}=-1.062804$, Prob $=0.0000$. The probability of $t$-statistics for company income tax is lower than the acceptable $5 \%$. Furthermore, the Adjusted R- squared which is the coefficient of determination shows the magnitude of variations caused on net investment by the explanatory variables (CIT, FSZ and LEV) to be 0.543 . This indicates that about $54.3 \%$ variation in net investment is attributed to the influence of the explanatory variables (CIT, FSZ and LEV) while the remaining $45.7 \%$ is caused by other explanatory factors outside this model and this is captured by the error term. Thus, the result indicates that company income tax has a strong negative relationship with net investment, since the adjusted $\mathrm{R}^{2}$ is above $50 \%$ at about $54.3 \%$, the stated independent variable in the model is good enough to explain net investment. The significance level is 0.0000 ; this in essence shows that there is a significant relationship between the variables.

Decision

From Table 4, at the adopted level of significance at 0.05 , the overall significance of the model with the Prob(F-statistic) $=0.000000$, which is less than 0.05 . Therefore, we reject the null hypothesis and accept the alternative, which upholds that company income tax has significant effect on net investment of communication firms listed on Nigeria Stock Exchange at 5\% significant level.

\section{Findings, conclusions and recommendations}

\subsection{Summary of findings}

Based on the analysis of data, the following findings emerged:

i. Information communication tax has a significant negative effect on net investment of communication firms listed on Nigeria Stock Exchange at 5\% level of significance.

ii. Education tax has a significant negative effect on net investment of listed communication firms at $5 \%$ significant level.

iii. Company income tax has a significant negative effect on net investment of communication firms listed on Nigeria Stock Exchange at 5\% significant level.

\subsection{Conclusions}

This study examined the effect of taxes on net investment of communication firms listed on the floor of the Nigerian Stock Exchange from 2010-2019 periods. Existing literature showed that researchers are yet to reach a consensus about the effect of taxes on net investment. This study has contributed to the research effort at empirical measure of the effect of taxes on net investment of listed communication firms. Panel data were sourced from the annual reports and accounts of the sampled firms. Inferential statistics using correlation analysis and panel least square regression were employed via E-Views 10.0 statistical software. Data analysis revealed that a relationship exists between taxes and net investment of communication firms. As disaggregated components, information communication tax, education tax and company income tax exerted a significant negative effect on net investment at $5 \%$ significant level.

\subsection{Recommendations}

The following recommendations were made in line with the findings and conclusion of this study:

i. In order to reverse the negative effect of information communication tax, communication firms should take advantage of depreciation tax shield as the depreciation amount calculated each year is used to reduce the amount of tax liability at the end of the year thus making funds available for further investment.

ii. Based on the inverse relationship that exist between education tax and net investment, this study recommends that communication companies should employ the services of tax experts to aid them in tax planning in order to reduce the net tax payment so as to increase their net investment. Again they should increase their asset size and ensure efficient use of those assets to reflect in the production turnover of the companies. 
iii. Since the findings of this study indicate that company income tax has a significant negative effect on net investment, Chief Executive Officers need to respond to each side accordingly to enable them achieve the objectives of the company and those of the shareholders. Very high corporate taxes in the country affect the net investment of the organization and the economy at large in the sense that companies do not have enough retained earning's to undertake effective projects that will lead to the growth of company and economic development.

\section{References}

1. Abiahu, M. C., \& Amahalu, N. N. (2017). Effect of taxation on dividend policy of quoted deposit money banks in Nigeria (2006-2015). EPH - International Journal of Business \& Management Science, 1-30.

2. Agbionu, C. U., Amahalu, N. N., Egolum, U. (2017). Attitudinal change, power of thought and empowerment: The Indisputable Nexus. Contemporary Issues in Business Management: A Multidisciplinary Approach, 354-360.53

3. Akele, O. (2018). History and evolution of the telephone. The communicator. Nigerian Communications Commission. https://www.ncc.gov.ng/thecommunicator/index.php?option=com_content \&view=article\&id=150:history-and-evolution-of-the-telephone\&option=com_content\&view=article\&id= 150:history-and-evolution-of-the-telephone. Retrieved 12.5.2018

4. Amahalu, N. N., \& Ezechukwu, B. O. (2017). Effect of cash holding on financial performance of selected quoted insurance firms in Nigeria. The Indisputable Nexus. Contemporary Issues in Business Management: A Multidisciplinary Approach, 361-386.

5. Amahalu, N. N., Egolum, P. U., \& Obi, J. C. (2019). Effect of e-accounting systems on financial performance of quoted deposit money banks in Nigeria. Faculty of Management Sciences, 2019 International Conference Proceedings, Nnamdi Azikiwe University, Awka, Anambra State, Nigeria, 437-449.

6. Aminu, A. A., \& Eluwa, D. I. (2018). The impact of tax reforms on government revenue generation in Nigeria. Journal of Economic and Social Development, 1(1), 1-10.

7. Amuka, J., \& Ezeudeka F. (2017). Tax incentives and the flow of foreign direct investment to nonoil sector: Empirical. Asian Journal of Social Sciences and Management Studies, 4(1), 57-64.

8. Atuma, U. (2018). Information technology tax. https://asknigeria.com.ng/topic/239/informationtechnology-tax. Retrieved 17.5.2018.

9. Bond, S., Klemm, A., Newton-Smith, R., Syed, M., \& Vlieghe, G. (2014). The roles of expected profitability, Tobin's $Q$ and cash flow in econometric models of company investment (Working Paper No. 04/12). London: Institute for Fiscal Studies.

10.Brunela, T. (2018). Does fiscal policy matters for economic growth? Empirical study of Albanian situation. Interdisplinary Journal of Research and Development, II(2), 9-12.

11.Chen, H., \& Chen, S. (2012). Investment-cash flow sensitivity cannot be a good measure of financial constraints: Evidence from the time series. Journal of Financial Economics, 103(8), 393-410.

12.Chirinko, R. S. (2015). Business fixed investment spending: Modeling strategies, empirical results, and policy implications. Journal of Economic Literature, 31, 1875-1911.

13. Estevao, M., \& Samake, I. (2017). The economic effects of fiscal consolidation with debt feedback. IMF Working Paper WP/13/136.

14.Fama, E., \& French, K. (2015). Financing decisions: Who issues stock? Journal of Financial Economics, 76 (5), 549-582.

15.Fazzari, S., Hubbard, R. G., Petersen, B. C., Blinder, A. S., \& Poterba, J. M. (2016). Financing constraints and corporate investment. Brookings Papers on Economic Activity, 1, 141-206.

16.Federici, F., \& Parisi, V. (2015). Do corporate taxes reduce investments? Evidence from Italian firm-level panel data. Cogent Economics \& Finance, 3(1), 1-14.

17.Garrison, S. (2018). Capital budgeting. http://www.studyfinance.com/lessons/capbudget/?page. Retrieved 23/9/2018

18.Lewellen, J., \& Lewellen, K. (2016). Investment and cash flow: New evidence. Journal of Financial and Quantitative Analysis, 51(4), 1135-1164.

19.Lin, B. (2017). Information technology capability and Value creation: Evidence from the US banking industry. Technology in Society, 29, 93-106. 
20.Okeke, M. N., Mbonu, C. M., \& Amahalu, N. N. (2018). Tax revenue and economic development in Nigeria: A Disaggregated Analysis. International Journal of Academic Research in Accounting, Finance and Management Sciences, 8(2), 178-199.

21.Okeke, M. N., Mbonu, C. M., \& Amahalu, N. N. (2018). Effect of tax revenue on economic development in Nigeria. International Journal of Research in Business, Economics and Management, 2(4), 25-61.

22.Oliveira, B., \& Fortunato, A. (2016). Firm growth and liquidity constraints: A dynamic analysis. Small Business Economics, 27, 139-156.

23.Rauh, J. (2017). Investment and financing constraints: Evidence from the funding of corporate pension plans. Journal of Finance, 61(6), 33-71.

24.Vaidya, D. (2018). Ratio analysis of financial statements. https://www.wallstreetmojo.com/ratioanalysis/ Retrieved 13.5.18.

25.Zwick, E., \& Mahon, J. (2017). Tax policy and heterogeneous investment behavior. American Economic Review, 107(1), 217-248. 